\title{
Administrative Findings, Reasons, and Stare Decisis
}

\author{
Kenneth Culp Davis*
}

LARGE BODY of judge-made law requires administrative action
to be supported by adequate findings of fact, and, with respect to reasons as distinguished from findings, the Supreme Court has recently enunciated what it calls "a simple but fundamental rule of administrative law"1 that "the orderly functioning of the process of review requires that the grounds upon which the administrative agency acted be clearly disclosed and adequately sustained." ${ }^{\prime 2}$ The courts have imposed upon the agencies requirements concerning findings and reasons which go well beyond those which appellate courts have imposed upon trial courts, and well beyond those which appellate courts have imposed upon themselves. The Supreme Court requires that the basis for administrative action "must be set forth with such clarity as to be understandable,"3 but the Supreme Court's opinions do not answer with such clarity as to be understandable the question whether the requirement of administrative findings and reasons stems from the Constitution, from statutory interpretation, or from common law. And when the Supreme Court sets aside administrative action for supposed lack of adequate findings, one is often left in doubt as to whether the real reasons relate to clarity of findings or to judicial disagreement with administrative policy.

Although the assumption is very common that administrative agencies typically deal with each problem as a unique occurrence instead of developing bodies of case law and following precedents," the principle of stare decisis is in fact about as strong in adjudications before federal regulatory agencies as it is in public law cases in the federal courts. Agencies, like courts, are permitted to create new law retroactively through case-to-case adjudication. ${ }^{5}$

* Visiting Professor of Law, Harvard University.

The writer is indebted to Associate Professor Frank C. Newman of the School of Jurisprudence, University of California, for especially helpful criticisms.

1 SEC v. Chenery Corp., 332 U.S. 194, 196 (1947).

2 SEC v. Chenery Corp., 318 U.S. 80, 94 (1943).

3 SEC v. Chenery Corp., supra note 1 at 196.

4 Pound, AN Introduction to ter PhIlOSOPHy of LAw 108, 109 (1922).

5 SEC v. Chenery Corp., 332 U.S. 194 (1947), discussed below at p. 253. 


\section{FINDINGS}

In discussing administrative findings, we shall consider (1) the Administrative Procedure Act, (2) the background of judicial practices, (3) the constitutional basis for the requirement, (4) practical reasons for the requirement, (5) ultimate facts and basic facts, (6) jurisdictional facts, (7) findings properly made without supporting evidence, and (8) the effect of substantive views on determinations of adequacy of findings.

\section{(1) The Administrative Procedure Act}

Probably no substantial change in the law of findings is made by the APA. After providing that parties may submit with supporting reasons proposed findings and conclusions and exceptions to recommended decisions, section 8 (b) provides:

The record shall show the ruling upon each such finding, conclusion, or exception presented. All decisions (including initial, recommended, or tentative decisions) shall become a part of the record and include a statement of (1) findings and conclusions, as well as the reasons or basis therefor, upon all the material issues of fact, law, or discretion presented on the record; and (2) the appropriate rule, order, sanction, relief, or denial thereof.

This provision applies only to orders and rules "required by statute" to be determined or made on the record after opportunity for an agency hearing, but the Supreme Court has held that the words "required by statute" include what is required by due process, because the constitutional requirement "permeates every enactment" and because a major purpose of the APA would otherwise be defeated."

The committees of both House and Senate implemented the statute in their reports: ${ }^{\top}$

Findings and conclusions nust include all the relevant issues presented by the record .... Where oral testimony is conflicting or subject to doubt of its credibility, the credibility of witnesses would be a necessary finding if the facts are material. It should also be noted

${ }^{6}$ Wong Yang Sung v. McGrath, 70 S. Ct. 445 (1950). The writer has discussed the problem in Separation of Functions, 61 HARv. L. REv. 389, 612, 630-36 (1948).

T SEN. Doc. No. 248, 79th Cong., 2d Sess. 210-11, 273 (1946). The House Committee may have gone too far when it said: "When made, decisions as defined by this section must be served on parties named, and also furnished to those participating as well as to interested persons who request them or have attempted to participate or intervene. Any person who requests in writing to be notified or given copies should have his request honored." Id. at 274. See also the statement of Representative Walter on the House floor. Id. at 36\%. 
that the relevant issues extend to matters of administrative discretion as well as of law and fact. This is important because agencies often determine whether they have power to act rather than whether their discretion should be exercised or how it should be exercised.

The principal problem of interpreting this provision of section 8 (b) is whether the agency must make a separate finding with respect to each proposed finding and exception. A single set of "findings and conclusions" may conceivably "show the ruling upon each such finding, conclusion, or exception presented" without doing so with respect to each one separately. This is the interpretation the SEC has given: "Where, as in these reorganization proceedings, hearings are protracted and many imterests are represented, we are often confronted with many sets of complicated proposed findings dealing with the same facts, but arranged in different order. To pass upon these seriatim would serve no useful purpose when there are complete findings, such as we have issued herein, and might well make it more difficult to ascertain the basic findings and the reasons underlying the Commission's conclusions." 8 This is well supported by the Attorney General's.Manual, which declares: "An agency which issues opinions in narrative and expository form may continue to do so without makmg separate findings of fact and conclusions of law." The House Committee said that the sentence requiring the record to show the ruling upon each finding was "added for the purpose of requiring agencies to note their rulings somewhere on the record in order to preclude later controversy as to what the agency had done." 10

In addition to section $8(\mathrm{~b})$, the APA has other provisions about findings and reasons. Section 4(b), applying to some rule making, provides that "the agency shall incorporate in any rules adopted a concise general statement of their basis and purpose." And section 6(d), requiring notice of denial of written applications, petitions, or other requests made in connection with any agency proceeding, provides: "Except in affirming a prior denial or where the denial is selfexplanatory, such notice shall be accoinpanied by a simple statement of procedural or other grounds."

The case law, as we shall see, deals with many problems left untouched by the APA.

8 The Commonwealth \& Southern Corp., Holding Company Act of 1935, Release No. 7357 (1947).

9 AtT'y Gen. Manuad on the APA 86 (1947).

10 Sew. Doc. No. 248, 79th Cong., 2d Sess. 288, n. 19 (1946). 


\section{(2) The Background of Judicial Practices}

Although administrative agencies should not necessarily imitate courts, a quick glance at practices of trial courts is helpful in appraising the administrative problem. The key fact is that most of the states probably do not require findings of fact and conclusions of law in cases tried by courts without juries. ${ }^{11}$ Before 1930 federal equity courts were not required to make special findings. ${ }^{12}$ Even under Rule 52 of the present Federal Rules of Civil Procedure, findings are not required in some classes of cases. ${ }^{13}$ England and the British Domimons impose no requirement of findings upon trial courts. ${ }^{14} \mathrm{~A}$ distinguished commentator on judicial procedure wrote in 1936: "The extraordinary amount of variation ainong Ainerican statutes dealing with written findings and conclusions is persuasive evidence of a want of any sound theory of procedural policy upon which they might be supposed to rest." 15 A California judge has recently discussed the problem of trial courts' findings and has concluded: "It is submitted that special findings have never been worth the price and that they should have gone out as they came in-in the stage coach days." 18 A Missouri judge discusses with approval a system of making findings only when specifically requested by counsel, commending a statute providing that "All fact issues upon which no specific findings are made shall be deemed found in accordance with the result reached."17 General verdicts, of course, are very common.

\section{(3) Does the Constitution Require Administrative Findings?}

In view of the widespread omission of findings by trial courts, the idea that the requirement of administrative findings may be grounded in the Constitution seems at first blush preposterous. But some au-

11 See 3 Moore, Federac Practice 3116 (1938), listing seventeen states requiring findings of fact in cases tried without juries. See also Hanson, Findings of Fact and Conclissions of Law, 32 A. B. A.J. 52 (1946) making the statement that in 1938 only eleven states required findings of fact.

12 Rule $70 \% / 2$ of the Federal Equity Rules, requiring findings of fact and conclusions of law, was adopted in 1930.

13 E.g., Baetjer v. United States, 143 F.2nd 391 (1st Cir. 1944) (findings not required in eminent domain proceeding).

14 Sunderland, Findings of Fact and Conclusions of Law in Cases Where Juries Are Waived, 4 U. of CHI. L. Rev. 218, 219 (1936).

$151 d$. at 221 .

16 Hanson, supra note 11, at 55 .

17 Hyde, A Modern Substitute for Findings of Fact and Conclusions of Law, 32 A.B.A. J. 131 (1946). 
thority does support this idea. In Panama Refining Co. v. Ryan, ${ }^{18}$ the Supreme Court said that "due process of law requires that it shall appear that the order is within the authority of the officer, board or commission, and, if that authority depends on determinations of fact, those determinations must be shown." 19 The Court accordingly held that the President's action, unsupported by a finding of facts, in prohibiting shipment in interstate commerce of petroleum produced in contravention of state laws was "without constitutional authority." 20 This view had some foundation in earlier opinions. In the Wichita Railroad case $^{21}$ the Court, somewhat vaguely, observed that the statute required findings to support a rate order, and then added: "The legislature, to prevent its being a pure delegation of legislative power, must enjoin upon it [the Commission] a certain course of procedure." Of the Wichita case, the Court said in Mahler v. Eby: "We held that the order in that case ... was void for lack of the express finding in the order. We put this conclusion not only on the language of the statute but also on general principles of constitutional government." Even as recently as 1941 the Supreme Court has relied on the requirement of findings as a prop for a decision upholding delegation of power: "The essentials of the legislative function are the determination of the legislative policy and its formulation as a rule of conduct. Those essentials are preserved when Congress specifies the basic conclusions of fact upon ascertainment of which, from relevant data by a designated administrative agency, it ordains that its statutory command is to be effective." ${ }^{23}$ Some state decisions have required findings as a matter of due process of law. ${ }^{24}$

Despite these authorities, the idea that the Constitution requires

18293 U.S. 388 (1935).

19 Id. at 432.

20 Id. at 433. The American Bar Association's Special Committee on Administrative Law, commenting on the Panama case, expressed the opinion that "the tests laid down by the majority of the Court cannot be followed with respect to ... the delegated power to make rules of conduct in the form of rules and regulations." 61 A. B.A. REP. 720, 777 (1936).

21 Wichita R. R. v. Pub. Util. Comm., 260 U.S. 48, 59 (1922).

22264 U.S. 32, 44 (1924).

23 Opp Cotton Mills v. Administrator, 312 U.S. 126, 145 (1941). The Court relied on the Opp case in requiring clarification of findings in United States v. Carolina Carriers Corp., 315 U.S. 475, 489 (1942). See also Yakus v. United States, 321 U.S. 414, 426 (1944).

24 E.g., Laney v. Holbrook, 150 Fla. 622, 8 So.2d 465 (1942); Appalachian Power Co. v. Commission, 132 Va. 1, 110 S. E. 360 (1922) (relying on a state constitutional provision). 
administrative findings seems untenable. The common practice of courts sitting without juries of omitting findings ought alone to be enough to show that findings are not constitutionally required for adjudications. ${ }^{25}$ True, the cases tending to make findings a constitutional requirement involve legislative rather than adjudicative action. But the Supreme Court has observed that procedurally a rate case "has a quality resembling that of a judicial proceeding. Hence it is frequently described as a proceeding of a quasi-judicial character." Even for legislative action, the requirement probably does not stem from the Constitution. The authorities before the Panama case denying existence of a constitutional requirement of findings are numerous and strong. ${ }^{2 \pi}$ Mr. Justice Cardozo's dissenting opmion in the Panama case was firmly buttressed by established doctrine: "The President was not required either by the Constitution or by any statute to state the reasons that had induced him to exercise the granted power .... The will to act being declared, the law presumes that the declaration was preceded by due inquiry and that it was rooted in sufficient grounds. Such, for a hundred years and more, has been the doctrine of this court." 28 In later opinions the Supreme Court has shown no inclination to put the requirement on a constitutional ground, and sometimes the requirement is not imposed. ${ }^{29}$

\section{(4) Practical Reasons for Requiring Findings}

Even though the requirement ought not to be considered as emanating from the Constitution, the practical reasons for requiring administrative findings are impressive. Both legislatures and courts have seen fit to impose the requirement, the courts sometimes interpreting or purporting to interpret statutory provisions and sometimes creating common law. The reasons have to do with facilitating judicial review, avoiding judicial usurpation of administrative functions, as-

25 See text supra at note 11.

26 Morgan v. United States, 298 U.S. 468, 480 (1936). Apart from this remark, of course, the assimilation of public utility rate cases to judicial procedure is well known.

$2 \pi$ The early cases are carefully reviewed by Cardozo, J., dissenting in Panama Refining Co. v. Ryan, 293 U.S. 388, 433, 444-48 (1935).

$28 \mathrm{Id}$. at 444. Mr. Justice Cardozo explained away the seeming reliance on constitutional doctrine in the Wichita and Mahler cases by showing that in both those cases "it was a specific requirement of the statute that the basic fact conditioning action by the administrative agency be stated in a finding and stated there expressly. If legislative power is delegated subject to a condition, it is a requirement of a constitutional government that the condition be fulfilled." Id. at 447-48.

29 Pacific States Co. v. White, 296 U.S. 176 (1935), and other cases discussed infra at note 62 et seg. 
suring more careful administrative consideration, helping parties plan their cases for rehearings and judicial review, and keeping agencies within their jurisdiction.

Much the most prominent reason discussed in judicial opinions is the facilitation of judicial review. A simple illustration will readily show the need for findings as an aid to judicial review. A statute provided that no milk license should be granted unless the commissioner "is satisfied that the applicant is qualified by character, experience, financial responsibility and equipment to properly conduct the proposed business, that the issuance of the license will not tend to a destructive coinpetition in a niarket already adequately served, and that issuance of the license is in the public interest." For the court to review a bulky record without knowing which of the six factors the commissioner found to be lacking would obviously be wasteful. Hardly surprising was the court's holding that "Only after the commissioner has made findings of fact can the court decide whether the findings are sustained by the evidence ... ."30 When issues are more complex and interdependent, the need for findings is even greater.

Mr. Justice Cardozo is often quoted: "We must know what a decision means before the duty becomes ours to say whether it is right or wrong." 31 The ICC in that case had made findings, but not "with the simplicity and clearness through which a halting impression ripens into reasonable certitude." 32 Mr. Justice Frankfurter has explained that the requirement "is merely part of the need for courts to know what it is that the Commission has really determined in order that they niay know what to review .... This is the real ground for the decisions which have found Interstate Commerce Commission orders wanting in necessary findings." ${ }^{33}$ If there were no law requiring findings, judges strugglimg with masses of evidence and hazy findings, trying their best to discover whether the agency has applied the proper principles, would surely invent such a requirement. Characteristic judicial remarks seem to manifest considerable patience: "We only reqnire that, whatever result be reached, enough be put of record to enable us to perform the limited task which is ours." 34

30 Elite Dairy Products v. Ten Eyck, 271 N.Y. 488, 498, 3 N. E. 2d 606, 610 (1936).

31 United States v. Chicago, M., St. P. \& P. R. R., 294 U.S. 499, 511 (1935).

32 Id. at 510.

33 Yonkers v. United States, 320 U: S. 685, 694-695 (1944) (dissenting opinion).

34 Eastern-Central Assn. v. United States, 321 U.S. 194, 212 (1944). In ColoradoWyoming Co. v. FPC, 324 U.S. 626 (1945), the Court asked a number of vital questions which were unanswered by findings, and set aside the order. Other such cases are discussed under the heading of "basic facts" below. 
A second practical reason for requiring findings-preventing judicial usurpation of administrative functions-applies to administrative agencies with much greater force than it does to trial courts sitting without juries. The basic difference is that the limitations on fact-finding by the reviewing court are greater when administrative action is reviewed than when judicial action is reviewed. ${ }^{35}$ No serious harm is done if an appellate court after reversing the trial court's determination of law makes the necessary findings and applies the right law so as to render a judgment. But when an agency because of erroneous law makes findings on the wrong issues, the reviewing court would usurp the administrative power if it were to make its own findings. To the extent that administrative specialization affects the fact-finding process, such usurpation would be unfortunate in immediate practical consequences. Therefore the reviewing court should sometimes send a case back to an agency for a new finding even though in similar circumstances it would not send the case back to a trial court for a new finding. Inadequacy of administrative findings often results from addressing the findings to the wrong issues. For instance, in I.C.C. v. Mechling, ${ }^{36}$ the Commission had approved a three cent higher reshipment rate for ex-barge grain east of Chicago than for ex-lake and ex-rail grain. Both the purpose and the effect of the higher rate east of Chicago was to diminish the competitive advantage of barges over railroads west of Chicago. The Court held that the law did not permit such a higher rate "unless the eastern haul of the ex-barge grain costs the eastern railroads more to haul than does ex-rail or ex-lake grain." Because of its view of the law, a view supported by two dissenting Justices, ${ }^{37}$ the Commission had made only a finding "in broad general terms" that "on the average" ex-rail grain requires less terminal and transit service east of Chicago than ex-barge grain. The Court pointed out that some ex-rail grain requires exactly the same terminal service as is rendered for ex-barge grain. Furthermore, the Commision made no finding as to how much, if any, of the three cent difference was attributable to the greater

${ }^{35}$ Cf. SEC v. Chenery Corp., 318 U.S. 80, 88 (1943): "Where the correctness of the lower court's decision depends upon a determination of fact which only a jury could make but which bas not been made, the appellate court cannot take the place of the jury. Like considerations govern review of administrative orders."

36330 U. S. 567 (1947). See also Connecticut Co. v. FPC, 324 U.S. 515, 532 (1945), where the order was set aside partly because: "The findings and opinion of the Commission leave us in doubt, to say the least, as to whether what we consider limitations on the jurisdiction of the Commission were so considered by it."

87 Frankfurter and Jackson, JJ. 
terminal service. The Court therefore set aside the order for lack of adequate findings. ${ }^{38}$ Assuming the Court's version of the law, no other course was practicable. ${ }^{39}$

A third practical reason for administrative findings is that findings help protect against careless or arbitrary action. ${ }^{40}$ Judge Frank gives this element first place: "It is sometimes said that the requirement that the trial judge file findings of fact is for the convenience of upper courts. While it does serve that end, it has a far more important purpose-that of evoking care on the part of the trial judge in ascertaining the facts." 41 Courts sometimes assert that the requirement of administrative findings is "to assure against Star chaniber methods." 42 Although that language may be too strong, especially in view of frequent omission of findings by trial courts, still a decision supported by specific findings seems obviously more likely to have its roots in the evidence and less likely to rest on caprice or slipshod consideration. Judge Frank's observation seems entirely convincing: "Often a strong impression that, on the basis of the evidence, the facts are thus-and-so gives way when it comes to expressing that impression on paper." 43 The surprismg fact here is the extent of opinion

38 In North Carolina v. United States, 325 U.S. 507 (1945), the Court divided five to four about adequacy of findings, but the basic difference concerned the substantive law.

39 Similarly, in Siegel Co. v. FTC, 327 U.S. 608 (1946), the Court had no way of knowing without further findings whether the Commission's action was proper. The company used the name "Alpacuna" for coats wbich contained alpaca, mohair, wool, and cotton but no vicuna. The Commission found that the name was deceptive because it induced the belief that the coats contained vicuna. It accordingly banned use of the name "Alpacuna." The Commission made no finding on the question whether qualifying language could be used so that deception could be avoided without banning the use of the trade name. The Court held: "We are left in the dark whether some change of name short of excision would in the judgment of the Commission be adequate. Yet tbat is the test .... the courts are not ready to pass on tbe question whether the limits of discretion have been exceeded in the choice of the remedy until the administrative determination is first unade." Id. at 613-14. The Court accordimgly remanded. That the Commission upon the remand found a way to permit the company to continue the use of its trade name and at the same time avoid deception shows the soundness of the Court's decision. See Jacob Siegel Co., 43 F.T.C. 256 (1946); 160 F. 2d 247 (1947).

40 See 1 Benjamin, Administrative Adjudication in the State of New York 253 (1942); Feller, Prospectus for the Further Study of Federal Administrative Law, 47 YaIE L. J. 647, 666 (1938).

41 United States v. Forness, 125 F. 2d 928, 942 (2d Cir. 1942), cert. denied, 316 U.S. 694 (1941). See also Frank, Say It with Music, 61 HARv. L. Rev. 921 (1948).

42 Saginaw Broadcasting Co. v. FCC, 96 F.2d 554 (D. C. Cir. 1938), cert. denied, 305 U.S. 613 (1938).

43 United States v. Forness, supra note 41. 
to the contrary. A federal judge has expressed a common point of view: "We all know, don't we, that when we hear a criminal case tried we get convinced of the guilt of the defendant or we don't; and isn't it enough if we say guilty or not guilty, without going through the form of making special findings of fact designed by the judge-unconsciously, of course - to support the conclusions at which he has arrived?" 44 A leading commentator on judicial procedure has asserted: "Having heard the evidence and found the facts the judge can gain nothing by informing himself in writing regarding what he already knows." 45

The fourth practical reason for findings is to help parties plan their cases for rehearings and for judicial review. Most of the reasons already discussed concerning facilitation of judicial review apply equally to facilitation of the parties' planning. Furthermore, a disappointed party, whether he plans further proceedings or not, deserves to have the satisfaction of knowing why he lost his case. As Henderson has so persuasively demonstrated in discussing the Federal Trade Commission, a party officially accused of illegal conduct may be unjustly treated through a mere announcement of general conclusions which fail to reflect the nature of the offense, the extenuating circumstances, and the concrete meaning of broad legal phrases imputing guilt. ${ }^{46}$

The fifth practical reason for findings, often stressed in judicial opinions, is to keep the agencies within their jurisdiction. The Supreme Court said in the Phelps Dodge case: "All we ask of the Board is to give clear indication that it has exercised the discretion with which Congress has empowered it." 47 In the Yonkers case, even though no party had raised any question before the Commission about its jurisdiction, the Court held: "the existence of federal authority to act should appear affirmatively . ..."48 This idea has been reiter-

44 Mclemlan (former federal district judge), Federat Rules of Crimtar ProCEDURE 173 (Holtzoff ed. 1946), quoted in Frank, supra note 39, at 926.

45 Sunderland, supra note 14, at 228. Professor Sunderland seems to approve the law of those states having statutes requiring trial courts to make no findings of fact unless requested "with a view to excepting to the decision of the court."

40 Henderson, The Federai Trade Comianssion c. III (1925) containing an unusually illuminating analysis of the findings problem.

47 Phelps Dodge Corp. v. NLRB, 313 U. S. 177, 197 (1941).

48 Yonkers v. United States, supra note 33, at 692. Of course, the idea of keeping agencies within jurisdiction overlaps with assisting judicial review. See United States v. Carolina Carriers Corp., 315 U. S. 475, 489 (1942): "If, as seems likely here, an erroneous statutory construction lies hidden in vague findings, then statutory rights will be whittled away." 
ated in later cases; ${ }^{49}$ we shall discuss it further in connection with findings of jurisdictional facts.

\section{(5) Ultimate Facts and Basic Facts}

The Supreme Court in many cases has differentiated between ultimate facts and basic facts, and the classification is a useful one. The Court's language in United States v. Pierce Auto Lines ${ }^{50}$ is representative: "such an ultimate finding [that an applicant for a motor carrier certificate was fit, willing, and able to perform the service proposed] was not enough ... in the absence of a basic finding to support it ...." In In another case the Court declared: "We have repeatedly emphasized the need for clarity and completeness in the basic or essential findings on which administrative orders rest." ${ }^{62} \mathrm{~A}$ third category includes facts more specific than basic facts; findings more specific than basic facts ordinarily are unnecessary: "The Commission is not compelled to annotate to each finding the evidence supporting it." 53

Theoretically, facts might be lined up on a scale from the most specific to the most general. ${ }^{54}$ At one end would be the evidence itself, and then the very detailed facts resulting from resolving particular conflicts in the evidence, sometimes called primary facts. The basic facts are more general than primary facts but more specific than

49 Connecticut Co. v. FPC, 324 U.S. 515, 532 (1945); North Carolina v. United States, 325 U.S. 507, 511 (1945).

50327 U.S. 515 (1946).

61 Id. at 533.

52 Colorado-Wyoming Co. v. FPC, 324 U.S. 626, 634 (1945). See also Morgan v. United States, 298 U.S. 468, 480 (1936); Florida v. United States, 282 U.S. 194, 215 (1931) ; Howard Hall Co. v. United States, 315 U.S. 495, 499 (1942).

Exceptional in its emphasis on the ultimate finding was the Court's statement in Group of Investors v. Chicago, M., St. P. \& P. R. R., 318 U.S. 523, 539 (1943): "Here, as in other situations ... it is the conclusion or ultimate finding of the Commission together with its reasons and supporting data which are essential." The Court in this case seemed unusually tender toward the Commission's findings: "Reasons which underlie the expert opinion which the Commission expresses on a plan of reorganization under $\$ 77$ need not be marshalled and labelled as findings in order to make intelligible the Commission's conclusion or ultimate finding or to make possible the performance on the part of the courts of the functions delegated to them."

53 United States v. Pierce Auto Lines, 327 U.S. 515, 529 (1946).

54 See the analysis in Saginaw Broadcasting Co. v. FCC, 96 F.2d 554, 559-60 (D. C. Cir. 1938), cert. denied, 305 U.S. 613 (1938), outlining an administrative process of four parts: "... (1) . . . evidence . . (2) . . . a determination of facts of a basic or underlying nature .... (3) from these basic facts the ultimate facts, usually in the language of the statute, are to be inferred, or not, as the case may be; (4) froin this finding the decision will follow...." 
ultimate facts. Usually the ultimate facts may be expressed in terms of a statutory standard-the rate is "fair and reasonable," the requirement is "fair and equitable," or the action is "in the public interest." Most of the judicial decisions holding administrative findings deficient focus upon what the courts call basic facts, but occasionally action is set aside because of inadequacy of ultimate facts.

Probably the outstanding decision holding a statement of ultimate facts inadequate is United States $v$. Baltimore \& Ohio R.R. ${ }^{55}$ A statute conferred power upon the ICC to prohibit use of equipment causing "unnecessary peril to life or limb." The Commission, on complaint by a labor union, had conducted an adversary hearing on the question of requiring power reverse gears instead of manually-operated gears on steam locomotives. The Commission's report discussed advantages and disadvantages of the two types of gears and concluded that the change should be required: "We conclude and find that the safety of employees and travelers on railroads requires that all steam locomotives built on or after April 1, 1933, be equipped with a suitable type of power-operated reverse gear." ${ }^{266}$ The Commission's order also required the power gear for locomotives built before April 1, 1933. The Court in an opinion by Mr. Justice Brandeis unanimously held the order void for want of "quasi-jurisdictional findings" 67 of "unnecessary peril to life or limb." Even that part of the order applying to locomotives built on or after April 1, 1933, was set aside. The Court said that whether locomotives equipped with liand gears cause unnecessary peril to life or limb "is left entirely to inference." 58 The Court seemingly found a lack of equivalence between a finding that safety requires the power gear and a finding that the manual gear causes unnecessary peril to life or limb. Yet it seems almost inconceivable that a tribunal could make the first finding and at the same time deny support for the second. The Commission liad discussed the advantages and disadvantages of the two gears, including the expense of making the change, and had expressed its conclusions in clear language. The meaning was unmistakable, even though the final conclusion was not expressed in the words of the statuteeven though, as the Court said, the specific satisfaction of the statutory requirement was left to inference. The Court's refusal to draw

5293 U.S. 454 (1935).

66 Id. at 463 , note.

57 Id. at 465 .

68 Id. at 464. 
that inference seems to involve insistence on mere form. Later cases do not support the idea that ultimate facts must be stated in the statutory language, ${ }^{59}$ although the Baltimore $\&$ Ohio case has been frequently cited with seeming approval.

The Baltimore \& Ohio case seems out of line with both earlier and later cases. The Supreme Court has often inferred findings of ultimate facts from the mere issuance of an administrative order. Thus, it has held: "every patent for public or Indian lands carries with it an implied affirmation or finding of every fact made a prerequisite to its issue ..." Mo More than a century ago Mr. Justice Story expressed the same thought in another form: "The argument is ... it is necessary to aver the facts which bring the exercise within the purview of the statute ... . When the President exercises an authority confided to him by law, the presumption is, that it is exercised in pursuance of law." ${ }^{11}$ The most significant modern decision in this direction is Pacific States Co. v. White, ${ }^{62}$ where the Court refused to require specific findings to support an exercise of rule-making power. A state administrative body had issued an order fixing specifications for containers of berries, with no supporting findings of fact. The Court held: "Where the regulation is within the scope of authority legally delegated, the presumption of the existence of facts justifying its specific exercise attaches alike to statutes, to municipal ordinances, and to orders of administrative bodies." ${ }^{\prime 3}$ The Court rejected a contention that the order was void for lack of special findings: "the statute did not require special findings; doubtless because the regulation authorized was general legislation, not an administrative order in the nature of a judgment directed against an individual concern." ${ }^{44}$ The

59 The best support in Supreme Court decisions is found in Panama Refining Co. v. Ryan, 293 U.S. 388 (1935), decided the same day as the Baltimore \& Ohio case. The psychological background for the two decisions may have been exceedingly important, even though the opinions do not reveal it. In the Panama case counsel for the government admitted in oral argument that no official or general publication of the order had been made, even though violation was criminally punishable. See CorwIN, The Presment 367 (1940). See also Note, 49 Harv. L. Rev. 827 (1936).

60 Dickson v. Luck Land Co., 242 U. S. 371,374 (1917).

61 Martin v. Mott, 12 Wheat. 19 (U.S. 1827). See also Cardozo, J., dissenting, in Panama Refining Co. v. Ryan, 293 U.S. 388, 446 (1935), and cases cited. In H.P. Welch Co. v. State, 89 N. H. 428 , 199 Atl. 886 (1938), aff'd, 306 U.S. 79 (1939), the court applied the principle that "in the absence of indications to the contrary, a general finding imcludes a finding of all the special facts necessary to sustain it."

62296 U.S. 176 (1935).

63 Id. at 186.

64 Ibid. 
same remark might well have been made in the Baltimore $\mathcal{E}$ Ohio case. ${ }^{65}$

The tendency of some lower courts to follow the Baltimore \& Ohio and Panama cases instead of the later and probably sounder Pacific States case has had unfortunate effects. Illustrative of this is Twin City Milk Producers Ass'n v. McNutt. ${ }^{66}$ The Food and Drugs Act provides that the administrator may fix definitions and standards of identity for food whenever in his judgment "such action will promote honesty and fair dealing in the interest of consumers." The court, relying on the Panama and the Baltimore \& Ohio cases, but without mentioning the Pacific States case, renanded the case to the administrator because the administrator had failed to state expressly that in his judgment the order would promote honesty and fair dealing in the interest of consumers. The case went back, the statutory words were formally recited, the case came to the court again, the court poimted to the supplementary finding in the words of the statute, and upheld the order. ${ }^{6 \pi}$ This is what Mr. Justice Frankfurter has called "marching the king's nien up the hill and then marching them down again ....".ss

Avoidance of undue formalism probably requires that findings of ultimate facts be implied from administrative action in some circumstances. But whenever the action may be supported by any one of two or more ultimate facts, express findings of the ultimate facts are especially helpful. ${ }^{99}$

In nuany cases in which ultimate findings are fully stated, administrative action is set aside for madequacy of findings of basic facts. Phelps Dodge Corp. v. NLRB ${ }^{\text {to }}$ may be an example. The Board

65 The view of the Pacfic States case has been rather fully consolidated. In Thompson v. Consolidated Gas Co., 300 U.S. 55, 69 (1937), the Court said, citing only the Pacific States case: "It is settled that to all administrative regulations purporting to be made under authority legally delegated, there attaches a presumption of the existence of facts justifying the specific exercise." (Italics supplied.) A similar statement was made in United States v. Rock Royal Co-Op, 307 U.S. 533, 567-68 (1939).

Cf. Landis, The Admintstrattve Process 149 (1938); Feller, supra note 40, at 668.

${ }^{66} 122$ F.2d 564 (8th Cir. 1941).

67 Twin City Milk Producers Ass'n v. McNutt, 123 F.2d 396 (8th Cir. 1941).

BS Yonkers v. United States, 320 U.S. 685, 694 (1944) (dissenting opinion).

69 See discussion of practical reasons for requiring findings, supra p. 223.

Of course, administrative orders are often set aside for lack of findings of either ultimate or basic facts. E.g., NLRB v. Fansteel Corp., 306 U. S. 240, 261 (1939), where an order of reinstatement of employees was unsupported by any kind of findings and was accordingly set aside.

70313 U.S. 177 (1941). The Act provides that "the Board shall state its findings of fact," but no difference attributable to this provision is perceptible. 
had power to order the company to offer employment to men against whom the company had discriminated, even though the men had secured equivalent jobs, if the Board "finds that to do so would effectuate the policies of the Act." The Board ordered such an offer of employment, stating that it was "further to effectuate the purposes and policies of the Act," and that "the effectuation of the policies of the Act patently requires the restoration." The Supreme Court held these findings inadequate: "From the record of the present case we cannot really tell why the Board has ordered reinstatement of the strikers who obtained subsequent employment. . . . it will avoid needless litigation and make for effective and expeditious enforcement of the Board's order to require the Board to disclose the basis of its order." 71 Three dissenting justices thought the findings adequate and emphasized that "There is neither claim nor evidence that reinstatement will not effectuate the policies of the Act." 72 In a later case the Board spelled out reasons for a similar order-reasons having to do with removal of coercive effects of the discrimination on other employees, providing reassurance of freedom to employees, and preventing the employer from perpetuating advantages gained by his discrimination. ${ }^{73}$ Presumably such a statement of reasons would satisfy the Court's requirement. If so, the remark of a commentator has a good deal of merit-that the long-run consequence of the Court's decision will be "the mechanical regurgitation of 'canned' findings on a subject as to which nobody can entertain any reasonable doubts concerning the Board's opinion." 74 Indeed, the Supreme Court itself decides many cases with per curiam opinions which do not spell out reasons. Of the practical reasons for requiring findings which we have examined above, none seems to apply to the circumstances of the Phelps Dodge case with any substantial force. Perhaps the explana-

A leading case requiring basic findings is Florida v. United States, 282 U.S. 194 (1931). Other outstanding older cases include: Atchison Ry. v. United States, 295 U.S. , 193 (1935) ; United States v. Louisiana, 290 U.S. 70 (1933); Manufacturers Ry. v. United States, 246 U.S. 457 (1918); Meeker \& Co. v. Lehigh Valley R. R., 236 U.S. 412 (1915).

71 Id. at 196, 197.

T2 Murphy, Black, and Douglas, JJ. Id. at 200, 201.

73. Ford Motor Co., 31 N.L.R.B. 994, 1099-1100 (1941).

74 Timberg, Administrative Findings of Fact, 27 WASE. U. L. Q. 62, 69 (1941). This article provides a valuable analysis, although the conclusions are substantially out of line with prevailing thought. See Jaffe, Administrative Procedure Re-examined: The Benjamin Report, 56 HaRv. L. REv. 704, 722-23 (1943). 
tion is that the case was concerned with reasons for a determination of policy and not with findings of fact.

In other cases presenting problems somewhat like that of the Phelps Dodge case, the Court often upholds the order and expresses dissatisfaction with the findings. In one case the Court said that FPC findings "leave much to be desired" but that they were not so vague and obscure as to make judicial review perfunctory. The majority in an ICC case asserted that the Commission's opinion was "not altogether clear" "but rejected the view of four dissenting justices who would have set aside the order because the Commission's reports "have an obscurity and vagueness which two full arguments before this Court have not dispelled." Sometimes the judicial objection seems to concern merely a lack of orderliness: "The finding of facts of the Board is not in the proper form. It has mingled therein statements of witnesses and expressions of opinion .... There should be a clean-cut statement of the ultimate facts without incorporating therein the evidence or the reasoning by which the Board arrived at its finding." 78 One judge has objected to "an intermixture of charges, evidence, argument, inference, opmion, recitals of underlying facts and findings of ultimate facts." 79

In some circumstances the reasons for sending a case back for findings of basic facts are very conpelling. In United States v. Carolina Carriers Corp. ${ }^{80}$ the Commission had restricted the scope of a motor carrier's "grandfather" certificate to a greater extent than the Supreme Court thought permissible under the statute. The Court first declared new substantive law: "The Commission may not atomize his, prior service, product by product, so as to restrict the scope of his operations, where there is substantial evidence in addition to his holding out that he was in 'bona fide operation' as a 'common carrier' of a large group of commodities of a whole class or classes of property." "si Then in light of this law the Court determined that "It is impossible to say that the standards which we have set forth were

75 Colorado Interstate Co. v. FPC, 324 U.S. 581, 594 (1945). See also United Air Lines v. CAB, 155 F.2d 169, 173 (D. C. Cir. 1946).

To ICC v. Columbus \& Greenville Ry., 319 U.S. 551, 555 (1943).

$7 \pi$. at 559 .

78 NLRB v. Thompson Products, 97 F. 2 d 13 (6th Cir. 1938).

79 Stephens, J., dissenting. in Bethlehem Steel Co, v. NLRB, 120 F. $2 d$ 641, 666

(D. C. Cir. 1941).

80315 U.S. 475 (1942).

81 Id. at $483-84$. 
applied to the facts in this record." ${ }^{82}$ The Court accordingly set aside the order.

\section{(6) Jurisdictional Facts}

To some extent findings of jurisdictional facts are subjected to special requirements not applying to findings of other facts. The tendency of the courts to treat jurisdictional facts as a special category predates Crowell v. Benson, ${ }^{83}$ which brought the concept of jurisdictional facts into such prominence. For instance, in 1923 the Supreme Court asserted that "alienage is a jurisdictional fact; and . . . an order of deportation must be predicated upon a finding of that fact." 84 In the leading case of Mahler v. Eby , $^{85}$ the Court said: "The defect is jurisdictional. There is no authority given to the Secretary to deport except upon his finding after a hearing that the petitioners were undesirable residents."

The outstanding recent case is probably Yonkers $v$. United States, ${ }^{86}$ in which an ICC order was set aside for lack of an explicit finding of jurisdiction, even though no party in the hard-fought proceeding before the Commision had raised any question about jurisdiction. The Court explained: "The insistence that the Commission make these jurisdictional findings before it undertakes to act not only gives added assurance that the local interests for which Congress expressed its solicitude will be safeguarded. It also gives to the reviewing courts the assistance of an expert judgment on a knotty phase of a technical subject .... This is not to insist on formalities and to burden the administrative process with ritualistic requirements. It

82 Id. at 488. In the companion case, Howard Hall Co. v. United States, 315 U.S. 495 (1942) the holding is substantially the same, the Court there making it clear that the proper disposition is a remand "to the Commission so that the basic or essentinl findings" may be made. In both cases Frankfurter and Jackson, JJ., dissented on the ground that the Court was reviewing too intensively an administrative determmation of policy within the Cominission's authority.

83285 U.S. 22 (1932).

84 Bilokumsky v. Tod, 263 U.S. 149, 153 (1923).

85 264 U. S. 32, 43 (1924). See also United States v. Chicago, M., St. P. \& P. R. R., 294 U.S. 499,505 (1935), turning on what the Court called "basic and jurisdictional" findings.

In Lubetich v. United States, 315 U.S. 50 (1942), a unanimous Court solemnly inquired into the question whether or not certain facts ought to be considered as "quasi jurisdictional," concluding on one point that "Whether appellant's name was on bis equipment can only be a factor bearing on the ultimate issue. It is in no sense "quasi jurisdictional." "

86320 U.S. 685 (1944). 
entails a matter of great substance." 87 Taken at face value, this pronouncement would require agencies to take evidence and find facts establishing jurisdiction, whether any party raises any question concerning jurisdiction or not. Such a working rule for all agencies would obviously be burdensome and profitless. Furthermore, the ascertainment of what is and what is not a jurisdictional fact is often difficult or impossible. Justices Frankfurter, Reed and Jackson lashed out against use of the concept: "'Jurisdiction' competes with 'right' as one of the most deceptive of legal pitfalls. The opinions in Crowell v. Benson ... and the casuistries to which they have given rise bear unedifying testimony of the morass into which one is led in working out problems of judicial review over administrative decisions by loose talk about jurisdiction." 88

Since 1944, when the Yonkers case was decided, both the majority and the dissenting justices have yielded their positions and have apparently, though none too clearly, come together in a compromise view. Special requirements as to some jurisdictional findings are still imposed, but the category of facts calling for special treatment does not include all so-called jurisdictional facts. In the earlier Carolina Carriers case, ${ }^{89}$ Justices Frankfurter and Jackson, dissenting, provide the main clue: "It is one thing to require the Interstate Commerce Commission to be explicit in finding jurisdictional facts before it invades conceded state power. It is a wholly different thing to read with a hostile eye the Commission's findings that a claim for exemption from conceded federal regulatory authority has not been sustained." In Connecticut Co. v. FPC, ${ }^{90} \mathrm{Mr}$. Justice Frankfurter wrote a majority opinion concurred in by Mr. Justice Jackson, quoting with approval from the Yonkers opinion and asserting: "Nothing except explicit findings excluding the grounds of state control gives assurance that the bounds of federal jurisdiction have been accurately understood and fully respected, and that state power has been considerately and deliberately overlapped." And in North Carolina v. United States, ${ }^{\text {g1 }}$ the Court cited the Yonkers and other cases and declared: "The foregoing cases also stand for the principle that the Interstate

87 Id. at 691-92.

88 Id. at 695 . The dissenting justices also observed: "This issue was never tendered to the Commission because the facts which deny it were never questioned in the proceedings conducted before it with vigor and ability by several protestants during the three successive stages that preceded a challenge in the courts." Id. at 697.

89 United States v. Carolina Carriers Corp., 315 U. S. 475, 491 (1942).

90324 U.S. 515, 532 (1945).

91325 U.S. 507, 511 (1945). 
Commerce Commission is without authority to supplant a stateprescribed intrastate rate unless there are clear findings, supported by evidence, of each element essential to the exercise of that power by the Commission." One may surmise that although the doctrine of the Yonkers case is still valid, it is restricted to such jurisdictional questions as those concerning the division of powers between nation and states. ${ }^{92}$

\section{(7) Findings Properly Made Without Supporting Evidence}

Judicial opinions customarily reiterate the proposition that "There must be evidence adequate to support pertinent and necessary findings of fact." ${ }^{93}$ In view of this commonplace proposition, the suggestion that some findings need not be supported by evidence may seem surprising. But the suggestion is a sound one and deserves specific recognition.

Some findings rest on judgment or discretion or policy, which in turn rests on the kind of facts that are not necessarily susceptible of proof. For instance, in Market Street R. $R$. v. Railroad Commission, ${ }^{04}$ the company contended that a rate order denied due process because it was unsupported by evidence and was based on the Commission's speculation and conjecture. In fixing the rate the Commission had made predictions which were not based on any particular testimony, and the company contended that "such predictive findings may be made only on expert testimony, subject to cross-examination, explanation, and rebuttal, and may not be based on the Commission's own expert knowledge." The Court rejected the contention: "We cannot say that it is a denial of due process for a commission so experienced as the record shows this Commission to have been with the affairs of this particular appellant to draw inferences as to the probable effect on traffic of a given rate decrease on such a record as we have here. Particularly would a conclusion of denial of due process be unwarranted where, as here, the Commission recognized the infirmity of any predictions, regarded its rate order as a temporary experiment for which no fixed period was set, and held open the proceeding to

92 The doctrine may extend to some other jurisdictional facts. Even Mr. Justice Frankfurter, who has been most vigorous im condemning the idea of jurisdictional facts (see, in addition to the Yonkers opinion, Estep v. United States, 327 U.S. 114, 142 (1946)) emphasizes the continued validity of $\mathrm{Ng}$ Fung Ho v. White, 259 U.S. 276 (1922), which is a special application of the idea of jurisdictional facts. See for instance, the Frankfurter opinion in Stark v. Wickard, 321 U.S. 288, 312 (1944).

23 Morgan v. United States, 298 U.S. 468, 480 (1936).

94324 U. S. 548 (1945). 
receive whatever lessons experience might teach." ${ }^{95}$ Thus the finding based on "speculation and conjecture," that is, on the Commission's judgment, was upheld, even though it was unsupported by particular evidence. ${ }^{96}$

Findings often depend on law and not on evidence. The most familiar instance of this is law establishing a presumption or a burden of proof. A fact unsupported by evidence is treated as if it were proved unless the evidence disproves the fact. The result is that the finding depends upon what has been developed in previous cases in which the presumption or burden of proof or substantive law has been established, and not upon the evidence in the present record. This is what happened in Republic Aviation Corp v. NLRB. ${ }^{9 r}$ Propositions of fact are often treated as rules of common law-a child under seven is incapable of felony, irresistible impulse is not a form of insanity, a woman is capable of bearing children as long as she lives. ${ }^{98}$ The same process of changing fact into law occurs in administrative adjudication. For instance, a series of ICC decisions established the proposition that a rate on iron and steel scrap in excess of seventy per cent of the rate on iron and steel products was unreasonable; the ICC quite properly relied on the rule for a finding rather than on evidence, in absence of evidence opposed to the rule. ${ }^{82}$ When a tribunal relies on such rules, findings are often upheld even though unsupported by evidence in the particular record. ${ }^{100}$

Sometimes the reason for tolerating a gap either between evidence and findings or between findings and decision has to do with limita-

95 Id. at 560-61.

98 Of course, the result may be explained by saying that the Commission could take official notice of the facts underlying its prediction. But such an explanation is only a partial one, for the Commission has not gone through the process of identifying the particular extra-record facts on which it relies.

97324 U.S. 793 (1945), discussed at length in the writer's Official Notice, 62 HaRv. L. REv. 537, 582 (1949). The Court approved a finding of unfair labor practice which rested upon a previous decision of the Board that an employer's prohibition of solicitation on company property is an unfair practice in absence of evidence of special circumstances.

98 In United States v. Provident Trust Co., 291 U.S. 272 (1934), the Court permitted a party to disprove with evidence the capacity of a woman to bear children.

${ }^{29}$ Summer \& Co. v. Erie R. R., 255 I. C. C. 475 (1943), rev'd, Erie R. R. v. United States, 59 F. Supp. 748, 751 (S. D. Ohio 1944). After the reversal the Commission reasserted its position. 262 I. C.C. 43 (1945). And the court then reasserted its position. 64 F. Supp. 162 (1945).

100 The best example in the administrative field may be Republic Aviation Corp. v. NLRB, 324 U.S. 793 (1945). Examples in courts would include almost any case in which a finding rests on a presumption. 
tions of human intellects or limitations on the magnitude of investigations that may be conducted in particular circumstances. Not all propositions of fact that are useful and used in the administrative process are susceptible of proof with evidence. Or developing the evidence would be inordinately expensive. A good illustration is Eastern-Central Assn. v. United States. ${ }^{101}$ The ICC had rejected rate schedules on linoleum filed by motor carriers to meet rail competition. The ground for the rejection was entirely clear: the schedule unjustly discriminated between the shipper of 20,000 pounds, the approximate capacity of a truck, and the shipper of 30,000 pounds, the approximate capacity of a rail car; the Commission declined to permit the inotor carriers to meet rail competition on 30,000-pound lots and at the same time to charge a substantially higher rate, not reflecting cost of service, on lots between 20,000 and 30,000 pounds. In the Commission's view the volume minimum rates for motor carriers should be geared to the capacity of motor trucks, not rail cars. The Commission specifically found that "the proposed rates, minimun 30,000 pounds, would give an unjust advantage to shippers of 30,000 pound lots." 102 The Commission further held that "The competition between rail and motor carriers ... does not constitute such a dissimilarity in circumstances and conditions as to render legal the proposed discrimination." 103 The Commission thus resolved the inain issues with clear and specific findings. But the Supreme Court held the findings inadequate. The Court first complained that "Whether this policy is now intended to apply to all forms of transportation, rail, motor and water, without regard to competitive conditions affecting two or niore of them, is not clear from the abbreviated reports made in this case." ${ }^{104}$ The Commission was apparently doing about what the Supreme Court does when it decides a case without making clear the extent to which the doctrine enunciated will be applied in other cases. The Court interpreted the Commission's decision as probably meaning that the sole criterion in determining whether volume minimum rates are discriminatory was reduction in cost. The Court then held as a matter of law that in some circumstances conpetitive disadvantage might justify what would otherwise be an unreasonable or a discriminatory rate. But this holding was not necessarily inconsistent

101321 U.S. 194 (1944).

102 Rugs and Matting from the East to Western Trunk Line Territory, 34 M.C.C. 641,649 (1942). Three commissioners dissented.

103 Id. at 648.

104321 U. S. 194, 201. 
with the Commission's announced view that "The extent to which competition between carriers may render discrimination and prejudice not unlawful must be decided upon the facts in each case."105 The Commission's view was quite clear that competition in this case did not render lawful what was otherwise discrimination and prejudice. The Court, however, chose to review not merely the Commission's application of its policy to this case but the Commission's general adoption of the broad policy, emphasizing the Commission's statement that "for the future we shall follow the policy announced ...." and that the case "was regarded and determined as a test case." ${ }^{106}$ It seems hardly surprising that the Court could not tell, "other than by sheer acceptance of the Commission's conclusion," 107 whether in other circumstances the factor of competitive disadvantage would outweigh discrimination in fact between classes of shippers. The three dissenting justices, in an opinion by Mr. Justice Frankfurter, were more acutely aware of the extreme burden the Court was imposing on the commission: "The present ruling apparently imposes upon the Commission the duty of pursuing such complicated and far-reaching investigations every tine a motor carrier rate that may have a relation to a railroad rate is found to be discriminatory in relation to another motor carrier rate affecting the same commodity. Such an investigation is an undertaking of vast scope.... To hold that the Commission must on its own initiative embark on such an investigation in a proceeding of this nature is to impose what may well be a crippling burden." 108

New York $v$. United States, ${ }^{109}$ the huge interterritorial freight rate case, involved a factual inquiry of such magnitude that it may have

10534 M.C.C. $641,648$.

100321 U.S. 194, 203.

107 Id. at 209. The Court could not tell "whether the proposed rates will give the motor carriers an undue competitive advantage as to shipments of 20,000 to 30,000 pounds, whether there will be discrimination in fact between classes of shippers, or whether though these things may result in the particular situation they will do so only by virtue of its peculiar features or by virtue of its conformity to conditions generally prevailing in regions competitive as between rail and motor carriers." Of the three clauses of this statement, the last is the one on which the Court's position is of questionable soundness.

108 Id. at 216-17. The dissenting justices would resort to the idea of burden of proof: "When the carrier seeks to supplant a lawful rate, as in the case here, the burden is on it to supply all the essential information to justify the proposed rate . . . If it does not do so, it has failed to sustain the duty cast upon it by law, and the Commission in so finding has duly exercised its authority." Id. at 218.

109331 U.S. 284 (1947). 
been beyond the Commission's power to carry out with precision. The Commission issued an interim order increasing rates in the Northeast ten per cent and reducing rates elsewhere east of the Rocky Mountains ten per cent. The investigation involved no less than a comparison of all southern and western class rates as a composite group with all northeastern rates, and a determination of whether differences were justified by differences in costs. Lack of uniform classifications made the task virtually impossible, and establishment of uniform classifications might take ten years. Yet the political pressure for immediate action, expressed in a 1940 enactment, ${ }^{110}$ could not be resisted. The observation of a dissenting Commissioner was not denied: "The report does not show, except in nebulous fashion, that the cost figures represent apportionment of totals, based on estimates; that they involve many assumptions and acts of judgment; and are not computations from direct, original cost figures for particular movements."111 The justifications for the methods used were the necessity for quick action, the magnitude of the task, and the temporariness of the order. Dean Jaffe has charmingly described the judicial response: "The majority of the Court was prepared to swallow this rather unpalatable pill. In part the Court deferred-justifiably-to the Commission's expert judgment, as in its acceptance of the cost studies. In part it broke up the objections, and gulped them down in small pieces with the appropriate ritualistic remarks, seeking thus to avoid their total logical impact."112 Mr. Justice Frankfurter pointed out in dissent: "The findings do not reveal how it happened that putting $10 \%$ on and taking $10 \%$ off respectively will beget just the right adjustment." 113 He reasoned that the Court had required explicit findings in support of ICC orders not having a reach comparable to the reach of this order, and that "when the outcome of legal issues is bound to cut deeply into economic relations on such a scale, it is not asking too much to ask the Commission to be explicit and definite in its findings on the elements that are indispensable to the validity of its order."114 The majority of the Court did not reply specifically to this argument,

11054 STAT. 902 (1940), 49 U.S. C. $\& 3(1)$ (1946).

111 Quoted by the Court, 331 U.S. 284, 354.

112 Jaffe, Administrative Findings or The Ameer in America, 34 CoRs. L. Q. 473, 482-483 (1949).

113331 U.S. 284, 353. Mr. Justice Jackson in his separate dissenting opinion did not discuss the question of findings.

114 Id. at 352. 
except by its action in approving the order. ${ }^{115}$ But Dean Jaffe does so very persuasively: "Mr. Justice Frankfurter states as self-evident that if in narrow matters exactness is demanded, how much more so where the whole fate of the country is to be affected. I suggest that it was this very breadth which made the normally valid criterion less relevant in the inter-territorial rate case ... . The distinction between the work of the legislature and the work of the administrator is one of degree. The Commission had been forced to undertake a task of large-scale legislation. To demand findings such as we should insist upon to uphold or reject a specific discrimination is to overlook this distinction. Indeed, it may be next to impossible to produce that order of findings in such a case." 116

\section{(8) Do Substantive Viezes of Judges Affect Determinations of Ade- quacy of Findings?}

The law of findings does not exist in a vacuum. It is appended to concrete cases having substantive ineaning. Study of Supreme Court opinions immediately suggests the question whether the law of findings is sometimes used as a convenient tool which discerning judges may delicately manipulate to provide such judicial control of administrative policies as the Court may find to be in the public interest in particular circumstances.

In six cases in which the Court divided as to adequacy of findings during a five-year period, some may discern a substantial correlation between the position of particular justices on questions of adequacy of administrative findimgs and their preferences on such substantive administrative policies as those which (1) strengthen the competitive power of railroads agaimst barges, ${ }^{117}$ (2) prevent a small motor carrier froln carrying on its competitive enterprise, ${ }^{118}$ (3) extend effective

115 The majority granted that no findings showed the rates in Official Territory (northeast) unreasonably low, noncompensatory, or that they otherwise threatened harmful effects upon revenues and transportation efficiency. But the Court said that the problems were of rate relationships, that to remove discrimination the Commission may adjust rates upwards and downwards within a zone of reasonableness, giving due consideration to the factors named in section $15 \mathrm{a}(2)$, that rates of return of southern and western carriers were higher than those of eastern carriers, and that the significance of the various factors "is for the Commission to determine; and, though we had doubts, we would usurp the administrative function of the Commission if we overruled it and substituted our own appraisal of these factors." Id. at 349. On the question of increasing eastern rates, the Court did not seem to be interested in specific findings.

$116 \mathrm{Jaffe}$, supra note 112, at 484-485.

11 'T. C. C. v. Mechling, 330 U. S. 567 (1947), discussed above at p. 225.

118 United States v. Carolina Carriers Corp., 315 U. S. 475 (1942), discussed above at p. 223. 
federal regulation to a large utility, ${ }^{119}(4)$ increase railroad rates over OPA opposition, ${ }^{120}$ (5) strike down proposed rates by which motor carriers try to make more effective their competition with railroads, ${ }^{121}$ and (6) help the South and West by a decrease in freight rates and hurt the East by an increase in freight rates. ${ }^{122}$ In all six cases the Court divided on the findings issue and supposedly did not pass upon the various administrative policies. The majority held the findings inadequate in the first five cases and adequate in the sixth. In the first and second cases, Black and Douglas were with the majority, and in both cases Frankfurter and Jackson dissented. In the third case, the justices who had very strict standards about findings in the first two cases relaxed them, and those whose standards were looser tightened them, for Frankfurter and Jackson were with the majority in holding the findings inadequate, and the dissenters included Murphy and Black. In the fourth case, the positions on strictness of the findings requirement are again reversed, for the majority included Black and Douglas, and the dissenters included Frankfurter and Stone. In the sixth case, the only one in which the findings were held adequate, the majority included Black and Douglas; Frankfurter dissented on the ground of inadequate findings and Jackson dissented on grounds related to administrative power.

Of course, any apparent correlation between views about adequacy of findings and views of some of the justices about substantive administrative policies may be attributable only to coincidence. But one who is trying to predict whether particular findings will be upheld may well heed an observation of Mr. Justice Black: "Hypercritical exactions as to findings can provide a handy but an almost invisible glideway enabling courts to pass 'from the narrow confines of law into the more spacious domain of policy." "123

\section{REASONS AND STARE DECISIS}

The erroneous assumption is very common that administrative agencies are necessarily different from courts in the extent to which they prepare reasoned opinions and rely on the principle of stare decisis. For example, Dean Pound has asserted: "We know exactly

119 Connecticut Co. v. FPC, 324 U. S. 515 (1945), discussed above at p. 235.

120 North Carolina v. United States, 325 U. S. 507 (1945), discussed above at p. 235. 121 Eastern-Central Assn. v. United States, 321 U. S. 194 (1944), discussed above at p. 238.

122 New York v. United States, 331 U. S. 284 (1947).

123 SEC v. Chenery Corp., 318 U.S. 80, 99 (1943) (dissenting opinion). 
what courts do, on what basis they act in doing it, and at least what they say as to their reasons for doing it. We have no such means of knowing what administrative bodies or agencies have done nor how and why they did it." ${ }^{124}$ In his Introduction to the Philosophy of Law, Dean Pound says: "Typically judicial treatment of a controversy is a measuring of it by a rule in order to reach a umiversal solution for a class of causes of which the cause at hand is but an example. Typically administrative treatment of a situation is a disposition of it as a unique occurrence, an individualization whereby effect is given to its special rather than to its general features."125 This assumption is by no means limited to the writings of Dean Pound. For example, John Dickinson asserts: "The substantive difference between the administrative procedure and the procedure at law is that the administrative tribunals decide controversies coming before them, not by fixed rules of law, but by the application of governmental discretion or policy." 126

Observations of this kind are unfortunate because they ignore the basic difference between administration and administrative adjudication. Lumping together all "administrative treatment of a situation," as does Pound, or all "adininistrative procedure," as does Dickinson, makes accurate generalization impossible, except to observe that practices are extremely diverse. The generalizations of Pound and Dickinson are false to the extent that they apply to administrative adjudication in the federal regulatory agencies.

Publication of Reasoned Opinions. Such agencies as the ICC, FCC, FPC, NLRB, CAB, and SEC prepare and publish reasoned opinions which in all respects resenble ordinary judicial opimions. The chief difference is that administrative opinions usually include more specific findings of fact than those contained in judicial opinions. The administrative opinions are collected and systematically published in numbered bound volumes, and cases are cited by volume and page after the manner of judicial opinions. A typical volume of such reports contains a table of cases reported and a table of cases cited. The large volumes known as "Agriculture Decisions," embracing the results of adjudication under such important measures as the Agricultural Marketing Agreement Act, the Commodity Exchange Act, the Packers and Stockyards Act, and the Perishable Agricultural Commodities Act, contaim not only such tables but also a very im-

124 POUND, CONTEMPORARY JURISTIC THEORY 24 (1940).

125 Pound, AN Introduction to the PEILOSOphy of LAw 108-09 (1922).

126 Dickinson, ADMmastrative JUSTICE AND tHE SUPREMACY OF LAW 35-36 (1927). 
pressive table of Agriculture Decisions cited by courts and other authorities. In the back of a typical volume of such administrative opinions is an index or an index-digest. Many other indexes and digests and case finders of various kinds are sprouting up; commercial publishers are taking advantage of opportunities to make available the results of administrative adjudication im more convement forms. ${ }^{127}$

A typical opinion of a regulatory agency contains a syllabus, findings of fact, discussion of questions of law and policy resembling a reasoned opinion of an appellate court, and the order entered. The agency's own prior decisions are customarily cited and followed or distinguished or occasionally overruled in about the same way that an appellate court deals with its own prior decisions. The principle of stare decisis is about as strong as it is in public law cases in federal courts. Even a quick examination of a typical volume of decisions of a federal regulatory agency will readily confirm this fact. A painstaking and thoroughly documented study of precedents in the ICC concluded: "It is doubtful whether the Commission decides cases in a manner fundamentally different from that of traditional courts."128 Studies of other agencies have led to similar conclusions. ${ }^{120}$ An elaborate inquiry into case law of the New York Public Service Commission demonstrates that that tribunal has been building a body of case law which guides the Commission in much the same way that the common law guides the courts. ${ }^{130}$ The Attorney General's Committee made a survey of agencies' habits with respect to stare decisis and reported: "It is a striking fact that in almost every instance the agencies' officers who were interviewed expressed the belief that they accorded to the precedents of their respective agencies as much weight

127 Shepard's United States citator includes Interstate Commerce Commission Reports, Valuation Reports, Motor Carrier Cases, Decisions of the Department of the Interior, Opinions of the Attorney General, Treasury Decisions, Board of Tax Appeals Reports, and Tax Court Reports. This service might well be extended to include reports of FCC, FPC, NLRB, CAB, SEC, Agriculture Department, Commissioner of Patents, and Comptroller General.

128 Pittman, The Doctrine of Precedents and the Interstate Commerce Commission, 5. Geo. WASH. L. Rev. 543, 579 (1937). .

${ }^{129}$ See Note, Stare Decisis in N.L.R.B. and S.E.C., 16 N.Y.U.L.Q. REv. 618 (1939).

130 Hyneman, The Case Law of the New York Public Service Commission, 34 Cor. L. Rev. 67 (1934). Of course, the large set of Public Utilities Reports Annotate and Public Utilities Reports New Series, together with the supporting P. U. R. Digest, is one of the best examples of systematic reporting of administrative opinions, including reports of ICC and FPC, as well as reports of state public service commissions. 
as is thought to be given by the highest court of a state to its own prior decisions." 131

One federal regulatory agency is glaringly deficient in its failure to prepare reasoned opinions and to develop a reliable body of case law. The Federal Trade Commission has published more than forty volumes of reported decisions, but it does not usually prepare or publish reasoned opinions. A typical FTC decision consists of a syllabus, a copy of the coinplaint, a statement of numbered findings of fact, a statement of conclusions, and the order. Each part of the report is written in stilted lawyers' language, with seldoin a gleam of the realities of the problem..$^{132}$ The statement of conclusions is usually in one or two sentences, and the Commission's own decisions are seldoin cited as precedents. The FTC has been often criticized for its failure to write reasoned opinions. ${ }^{133}$

Some agencies, of course, do not and should not pubhish reasoned opinions in all adjudications. The Social Security Board selects some opinions as "precedent opinions," and the Railroad Retirement Board indexes and relies upon General Counsel's opimons in significant cases. The United States Employees' Compensation Commission uses court decisions rather than its own decisions as precedents on workmen's compensation problems. ${ }^{134}$ The Post Office Department, some of whose adjudications are especially well adapted to systematic publication of reasoned opimons, ordinarily prepares no such opinions. Some of the less prominent administrative authorities have long published reasoned opinions-the Comptroller General, the Commissioner of Patents, the Department of the Interior. ${ }^{135}$

131 Rep. AtT'y Gen. Conar. AD. Proc. 466 (1941).

132 Occasionally disagreement within the Commission produces reasoned opinions. See, for instance, Jacob Siegel Co., 43 F. T. C. 256 (1946).

133 E.g., ReP. AtT'y Gen. Comar. Ad. Proc. 136-37 (1941): "The Committee accordingly recommends that every effort be made to improve the form of the [Federal Trade] Commission's decisions .... and that such decisions include a discussion of the facts and contentions of the parties and the reasons underlying the ultimate judgment." See also Henderson, The Federal Trade Commisston 334 (1925) ; Landis, The AdMmintstratrve Process 105 (1938).

134 The Attorney General's Committee recognized that all orders of the Employees' Compensation Commission should not be accompanied by opinions, but recommended that reasoned opinions should be prepared in "cases of sufficient complexity or importance." See REPorT 165-66 (1941).

135 Even rules are often supported by reasons. Section $4(b)$ of the APA requires for some rules the incorporation of "a concise general statement of their basis and purpose." The outstanding experience of this kind is that of the Office of Price Administration. The Act provided: "Every regulation or order [of general applicability and 
For adjudications of substantial magnitude, like most adjudications of the federal regulatory agencies, the desirability of systematically publishing reasoned opinions is clear. Their preparation affords a safeguard against arbitrary or careless action, and the resulting body of precedents makes for consistency and predictability. Disadvantages ${ }^{136}$ relate to time and expense of preparation, expense to practitioners of maintaining accessible bodies of reports, and, perhaps, the hard fact of finite shelf space in law libraries. Some administrative publications of decisions become so numerous and bulky as to become unwieldly; tax lawyers are sometimes irked by the quantity of printed material emanating from the Bureau of Internal Revenue. The problem from this angle is of course a wholly practical one; much can be said for a practice of both courts and commissions of publishing opinions only in those cases which seein to have special value as precedents. A suggestion that publication of full opmions of courts in one-quarter of the cases "will come nearer to satisfying the demands of common sense and justice" may well be sound for the work of many courts and many agencies. ${ }^{13 \pi}$

Since most courts, including the Supreme Court, often decide cases without opinions, administrative opinions can hardly be a requirement of due process of law. The Court of Claims once asserted that the requirement of written opinions is a "cardinal principle of Anglo-Saxon jurisprudence." 138 Of this dictum Professor Radin has

effect] shall be accompanied by a statement of the considerations involved in the issuance of such regulation or order." 56 STAr. 24 (1942), 50 U. S. C. \$902 (1946). A commentator expressed the opinion that the statements of considerations "are an invaluable source of information, as well as very helpful aids in construction and interpretation of the regulations or the amendments thereto .... The statement of considerations is -worthy of a lasting place in administrative law." Willis, The Literature of OPA, 42 MICE. L. REV. 235, 246 (1943). The requirement of a statement of considerations was judicially interpreted as meaning "only a summary statement of the basic facts which justify the regulation," and not formal findings of fact. Montgomery Ward \& Co. v. Bowles, 138 F. 2d 669, 671 (Em. Ct. App. 1943).

136 Dean Pound in 1919 emphasized the "danger" that administrative bodies "will do what the courts have done before them: crystallize particular applications to particular cases into rules and thus destroy the standard." Pound, The Administrative Application of Legal Standards, 44 A. B. A. Rep. 445, 463 (1919). Of course, a general replacentent of the needed flexibility of discretion with a set of wooden rules could be disastrous. But so far no such development seems at all imminent, except possibly in the ICC to some slight extent. Compare Dimock, Some Aspects of American Administrative Law, 9 J. OF PUB. AD. 417, 418 (1931): "every administrative service worthy of the naine should have as one of its objectives administration hy and through law, i.e., with definite standards and hence devoid of any arbitrary action."

137 Radin, The Requirement of Written Opinions, 18 CALIF. L. REv. 486, 496 (1930). 138 John T. Ayres v. United States, 44 Ct. Cl. 48 (1908). 
written that 'the word 'cardinal,' the word 'principle' and the word 'Anglo-Saxon' are somewhat excessive." 139 Professor Radin points out that courts in California, ${ }^{140}$ Arkansas, ${ }^{141}$ and Montana ${ }^{142}$ have held statutory requirements of written judicial opinions to be unconstitutional, and courts in eight states ${ }^{143}$ have interpreted such requirements to be directory and not mandatory. For compelling unwilling agencies to prepare opinions, due process is a much less promising weapon than section 8(b) of the Administrative Procedure Act which, for determinations required by statute to be made on the record after opportunity for agency hearing, requires not only findings and conclusions but also a statement of "the reasons or basis therefore, upon all the material issues of fact, law, or discretion presented on the record ...."144

Deviation from Stare Decisis. Not only does due process permit omission of reasoned administrative opinions but it probably also permits substantial deviation from the principle of stare decisis. Like courts, ${ }^{145}$ agencies may overrule prior decisions or practices and may

139 Radin, stpra note 137 at 490.

140 Houston v. Williams, 13 Cal. 24, 73 Am. Dec. 565 (1859).

141 Vaughn v. Harp, 49 Ark. 160, 4 S. W. 751 (1887).

142 State v. District Court, 40 Mont. 206, 105 Pac. 721 (1909).

143 Missouri, Florida, Maryland, West Virginia, Kansas, Nebraska, Iowa, and Indiana. Radin says that only in Ohio and Texas has the requirement been accepted and enforced without judicial objection.

${ }^{141}$ Sections 3(b) and 8(b) of the APA seem carefully designed to avoid the requirement either of preparation of reasoned opinions in all cases or of publication of such opinions as are prepared. An example of a minimum performance is the Post Office Department's handling of fraud order cases; a regulation provides: " $\$ 1.17 \ldots$ (a) There shall he made available for public inspection: (1) All final opinions or orders in the adjudication of cases, except those required for good cause to be held confidential and not cited as precedents." 13 FED. REG. 8847 (1948). The only publication of fraud orders appears in the Postal Bulletin which is published twice weekly; findings are not published. The Department might do well to prepare reasoned opinions in some cases, to be puhlished and used as precedents.

The requirement of section $3(\mathrm{~b})$ is less exacting: "Every agency shall publish or, in accordance with pubbished rule, make available to public inspection all final opinions or orders in the adjudication of cases (except those required for good cause to be lield confidential and not cited as precedents) and all rules."

145 Cf. Mr. Justice Brandeis, dissenting, in Burnet v. Coronado Oil \& Gas Co., 285 U.S. 393, 406-08 (1932): "Stare decisis is usually the wise policy, because in most matters it is more important that the applicable rule of law be settled than that it be settled right . . . . But in cases involving the Federal Constitution, where correction through legislative action is practically impossible, this Court has often overruled its earlier decisions. The Court bows to the lessons of experience and the force of better reasoning, recognizing that the process of trial and error, so fruitful in the physical sciences, is appropriate also in the judicial function." Mr. Justice Brandeis lists many overruled and overruling cases in support of his statement that "This Court has, in mat- 
initiate new policy or law through adjudication. Perhaps the best authority for this observation is FCC $v$. WOKO. ${ }^{148}$ The Commission denied renewal of a broadcasting license because of misrepresentations made by the licensee concerning ownership of its capital stock. Before the reviewing courts one of the principal arguments was that comparable deceptions by other licensees had not been dealt with so severely. A unanimous Supreme Court easily rejected this argument: "The mild measures to others and the apparently unannounced change of policy are considerations appropriate for the Commission in determining whether its action in this case is too drastic, but we cannot say that the Commission is bound by anything that appears before us to deal with all cases at all times as it has dealt with some that seem comparable." ${ }^{147}$ In rejecting a similar argument that the SEC without warning had changed its policy so as to treat the complainant differently froin others in similar circumstances, Judge Wyzanski said: "Flexibility was not the least of the objectives sought by Congress in selecting administrative rather than judicial determination of the problems of security regulation ... . The administrator is expected to treat experience not as a jailer but as a teacher." 148 Chief Justice Vinson, speaking for a Court of Appeals, once declared: "In the instant case, it seems to us there has been a departure from the policy of the Commission expressed in the decided cases, but this is not a controlling factor upon the Commission." 140 Other similar authority is rather abundant. ${ }^{150}$ Possibly the outstanding decision the

ters deemed important, occasionally overruled its earlier decisions although correction might have been secured by legislation." He lists a larger number where correction by legislative action was not possible.

Perhaps even to a greater extent, administrative problems of social science invite trial-and-error processes, even when the vehicle for law-making is adjudication.

146329 . U.S. 223 (1946).

${ }^{147} I d$. at 228 . A note struck by the court below was omitted from the Supreme Court's opimion: "radical departures from administrative interpretation consistently followed cannot be made except for most cogent reasons. Indeed it has been said that the adoption by an administrative agency of different standards for similar situations amounts to acting arbitrarily." WOKO v. FCC, 153 F.2d 623, 630 (D. C. Cir. 1946).

148 Shawmut Ass'n v. SEC, 146 F. 2d 791, 796-97 (1st Cir. 1945).

140 Courier Post Pub. Co. v. FCC, 104 F. 2d 213, 218 (D. C. Cir. 1939).

150 Virginian Ry. v. United States, 272 U. S. 658, 665-66 (1926): "This Court has no concern with the correctness of the Commission's reasoning, with the soundness of its conclusions, or with the alleged inconsistency with findings made in other proceedings before it." Churchill Tabernacle v. FCC, 160 F.2d 244, 246 (D.C. Cir. 1947); Northern Pac. Ry. v. United States, 41 F. Supp. 439, 446 (D. Minn. 1941), aff'd, 316 U.S. 346 (1942); NLRB v. Baltimore Transit Co., 140 F.2d 51, 55 (4th Cir. 1944), cert. deried, 321 U.S. 795. 
other way, unless the dissenting opinion in the second Chenery case ${ }^{150 a}$ is regarded as authority, is NLRB v. Mall Tool Co. ${ }^{151}$ The Board in ordering back pay for employees wrongfully discharged had in the court's opinion departed from its usual rule of ordering back pay only from time of filing charges, when filing of charges is unreasonably delayed and no mitigating circumstances are shown. The Court, assuming unto itself the Board's power to find facts,.said: "We find in the record no mitigating circumstances justifying the delay." "152 Then it modified the order on the ground that "Consistency in administrative rulings is essential, for to adopt different standards for similar situations is to act arbitrarily." 153 From the standpoint of an ideal system, one can hardly disagree with the court's remark. But from the standpoint of a workable system, perhaps the courts should not impose upon the agencies standards of consistency of action which the courts themselves customarily violate. ${ }^{154}$ Probably deliberate change in or deviation from established administrative policy should be permitted so long as the action is not arbitrary or unreasonable. ${ }^{155}$ This is the view of most courts.

The Chenery Cases. The first and second Chenery cases $^{156}$ throw important light upon the law concerning statement of reasons in support of administrative decisions, and upon the law about administrative creation of new law through adjudication.

The Chenery cases began with an SEC order ${ }^{167}$ approving a plan

150a SEC v. Chenery Corp., 332 U.S. 194 (1947) fully discussed infra, at note 175. 151119 F. 2 d 700 (7th Cir. 1941).

$182 I d$. at 702 .

163 Ibid.

154 Every lawyer is probably familiar with lines of judicial decisions which involve striking inconsistency or wavering. A well-known example in the federal tax field goes from Klein v. United States, 283 U.S. 231 (1931), to Helvering v. St. Louis Trust Co., 296 U.S. 39 (1935), to Helvering v. Hallock, 309 U.S. 106 (1940).

155 FPC v. Hope Gas C0., 320 U. S. 591 (1944) is a good illustration of both judicial and administrative building and rebuilding of law through cases. The Court there relieved the Commission from former restraints concerning valuation of property for rate-making purposes, with the result that the Commission was left an unusually broad discretion to work out its own methods of valuation. The Commission's own precedents, and those of the courts, were no longer controlling, since they were largely devised under the rejected theory. The Court thus gave the Cominission a clean slate, with an unusually broad discretionary power to work out its own methods of valuation. But in this very case, what a startling departure from stare decisis the Court itself made in deciding that the statutory term "just and reasonable" ought to be given a meaning it did not have when the Act was passed!

156 SEC v. Chenery Corp., 318 U.S. 80 (1943) ; SEC v. Chenery Corp., 332 U.S. 194 (1947).

$15 \pi$ Federal Water Service Corp., 8 S. E. C. 893 (1941). 
of reorganization under the Public Utility Holding Company Act, but refusing to permit officers, directors, and controlling stockholders (the management), who had purchased preferred shares of the company during the period of reorganization, to participate in the reorganization equally with other holders of preferred stock. The Commission allowed the managenent no more than the purchase price plus accumulated dividends. The Commission found neither fraud nor lack of disclosure but held that the management's "duty of fair dealing with the persons for whom it acts is as great as is that of a trustee who holds title to a res for the benefit of his beneficiaries." 158 Under the statute, the Commission's task was to determine whether the terms of the reorganization were "fair and equitable" or "detrimental to ... the interest of investors." The Commission specifically stated that it was interpreting and applying the statutory standards ${ }^{160}$ and made a specific finding in the statutory terms. If the Commission had merely announced the finding and the conclusion, without writing a supporting opinion, presumably the Court would have held findings and reasons adequate, for the FTC customarily does no more and yet its orders are usually upheld. But the SEC went on and discussed reasons, including judicial authorities. After citing and quoting from judicial decisions concerning other fiduciaries, the Commission said: "We think that the authorities heretofore cited are fully applicable to the position of the management of a corporation trading in the securities which will be affected by a voluntary plan of reorganization upon which the management is working." 160

The Supreme Court, five to three, set aside the order. ${ }^{101}$ The majority, in an opinion by Mr. Justice Frankfurter, laid down the broad propositions that "the orderly functioning of the process of review requires that the grounds upon which the administrative agency acted

158 Id. at 916.

159 "Deciding whether the terms of issuance of the new common stock are fair and equitable or are detrimental to the interests of investors, we must find that they are unfair, inequitable, and detrimental, so long as the preferred stock purchased by the management at low prices is to be permitted to share on a parity with other preferred stock." Id. at 920.

160 Id. at 919. The Commission also pointed out that the principles applied to trustees "have been applied to persons whose fiduciary position arises.from the fact that they act for others in the formulation of a reorganization plan. The principles have been codified in Section 249 of the Bankruptcy Act, but the application of the principle does not depend on the existence of a statute. It depends on the broad equitable principles enunciated in the cases heretofore cited." Id. at 917.

161 SEC v. Chenery Corp., 318 U.S. 80 (1943). See Dodd, The Chenery Corporation Case, 56 Harv. L. Rev. 1002 (1943). 
be clearly disclosed and adequately sustained," 162 and that "The grounds upon which an administrative order must be judged are those upon which the record discloses that its action was based." 103 The Court recognized that this was a stiffer rule than that applied to the review of decisions of lower courts: "we do not disturb the settled rule that, in reviewing the decision of a lower court, it must be affirmed if the result is correct 'although the lower court relied upon a wrong ground or gave a wrong reason. " 164 The justification for the difference is that a reviewing court may formulate the ground upon which a lower court should have acted but may not initially decide a question which is committed to an agency for initial determination.

The Court then examined the Commission's opimion and found that "the Commission stated that it was merely applying 'the broad equitable principles enunciated in the cases ...."165 The word "merely" is that of the Court, not that of the Commission. The Court said that the Commission "formulated no judgment upon the requirements of the "public interest or the interest of investors or consumers' in the situation before it." ${ }^{166}$ Just how the Court extracted this conclusion from the Commission's report is far from clear, in view of the Commission's discussion of interest of investors and the Commission's explicit statement: "we find that the provisions for participation by the preferred stock held by the management result in the terms of issuance of the new securities being detrimental to the interests of investors and the plan being unfair and inequitable." ${ }^{167}$ The Court evidently meant that the Commission in arriving at that conclusion had relied upon the equity cases; in the view of the Court the Commission should have said somewhere in its opinion that it was relying on its "special administrative competence."

What comes next in the Court's opinion is ambiguous: "Had the Commission, acting upon its experience and peculiar competence, promulgated a general rule of which its order here was a particular application, the problem for our consideration would be very different. ... before transactions otherwise legal can be outlawed or denied their usual business consequences, they must fall under the ban of some standards of conduct prescribed by an agency of government

162 Id. at 94 .

168 Id. at 87 .

104 Id. at 88 .

165 Id. at 87 .

166 Id. at 92 .

1678 S.E. C. 893,921 
authorized to prescribe such standards-either the courts or Congress or an agency to which Congress has delegated its authority." 10s

Does this mean that the Commission can deprive the management of its profits only by an exercise of its rule-making power? One should have supposed that the transactions could be outlawed by an administrative interpretation and application of the broad statutory standards in the particular adjudication. That is the customary system of both judicial and administrative law-making in such circumstances. The Court, however, seems to say that the Commission may proceed only by rule-making, not by adjudication. Yet at the end of its opinion, the Court places the decision solely on expression of the wrong reasons: "We merely hold that an administrative order cannot be upheld unless the grounds upon which the agency acted in exercising its powers were those upon which its action can be sustained." 169

Upon the remand, the SEC wrote a new opinion reaching the same conclusion. ${ }^{170}$ With respect to retroactive law-making the Commission pointed out that members of the management must have known that they were running some risk, that the Commission would disapprove the profits, and that criticism had been voiced at the hearings with respect to their early purchases of preferred stock. The Commission observed that in 1934 the reorganization provisions of the Bankruptcy Act had notified reorganization managers that claims asserted by them in respect of the debtor's securities might be limited to the consideration paid, and that although this law was not directly applicable it "indicated a climate of opinion in which at least some reasonable men considered transactions of this character to be fraught with temptation and of dubious propriety."171 With respect to acting by order instead of by rule the Commission said:

168318 U.S. $80,92-93$ (1943).

169318 U.S. 80,95 (1943).

Three justices dissented in an opinion by Mr. Justice Black: "I can see nothing improper in the Commission's findings and determinations. On the contrary, the rule they evolved appears to me to be a salutary one, adequately supported by cogent reasons and thoroughly consistent with the high standards of conduct which should be required of fiduciaries. That the Commission saw fit to draw support for its own administrative conclusion from decisions of courts should not detract from the validity of its findings .... . Of course, the Commission can now change the form of its decision to comply with the Court order." Id. at $97,99$.

170 Federal Water Service Corp., 15 S. E. C. 849 (1944).

1TI SEC Holding Company Act No. 5584 (Feb. 7, 1945). 
The Supreme Court indicated the advisability of pronulgating a general rule, though we do not understand its opinion to hold that the absence of a pre-existing rule is fatal to the decision we have reached. ... We may well decide that a general rule, with adequately flexible provisions, would be both practicable and desirable; but we do not see how the promulgation of such a rule now or later would affect our duty to act by order in this case in deciding whether this plan is fair and equitable and meets the other standards of the Act. We therefore reserve for further consideration the question whether or not a rule should be adopted. ${ }^{172}$

The Supreme Court, five to two, sustamed the Commission's new order. ${ }^{173} \mathrm{Mr}$. Justice Burton concurred only in the result. Mr. Justice Murphy for the four justices began with a reiteration of the holding in the first case: "If the administrative action is to be tested by the basis upon which it purports to rest, that basis must be set forth with such clarity as to be understandable." ${ }^{174}$ He said nothing about a similar requirement for Supreme Court opimions; the Frankfurter opinion in the first case was so unclear that on the question whether the Commission could proceed only by rule the Court of Appeals ${ }^{15}$ took the opposite view from that of the Commission, and only one of Mr. Justice Frankfurter's colleagues agreed with his interpretation of his own opinion. Mr. Justice Murphy declared that although "filling in the interstices of the Act should be performed, as much as possible, through this quasi-legislative promulgation of rules," "case-by-case evolution" has its place, and "the choice . . . lies primarily in the informed discretion of the admimistrative agency."177 On the question of retroactivity, the Court said that "Every case of first impression has a retroactive effect . . . But such retroactivity must be balanced against the mischief of producing a result which is contrary to a statutory desigu or to legal and equitable principles."118 Because the Commission's order did not lack "any rational and statutory foundation," 179 the Court sustained it.

The propositions set forth in the Murphy opimion seem orthodox and commonplace in all respects. Extension of old principles to new circumstances, apphication of existing standards in a way they have

172 Ibid.

173 SEC v. Chenery Corp., 332 U.S. 194 (1947).

$174 I d$. at 196.

176 Chenery Corp. v. SEC, 154 F. 2 d 6 (D. C. Cir. 1946).

178332 U.S. 194, 202 (1948).

177 Id. at 203.

178 Ibid.

178 Id. at 207. 
not been previously applied, use of a recognized "climate of opinion" as a basis for expansion of established protections, development of new law through the process of adjudication-all this amounts to no more than an administrative imitation of what courts have done from time immemorial. The Supreme Court in the second Chenery case held no inore than that the SEC in its field, within the framework laid down by Congress, may by case-to-case adjudication develop new law in the same way that the courts have created an elaborate structure of common law.

A dissent from such a holding is surprising. Even more surprising is a dissent more vehement than any other in the Supreme Court in recent times. Mr. Justice Jackson, with Mr. Justice Frankfurter concurring, said that the result was to "put most administrative orders over and above the law,"180 and that "the Court approves the Commission's assertion of power to govern the matter without law." The opinion bristles with emotional phrases_- "administrative authoritarianism," 181 "conscious lawlessness." 182

The main theme of the Jackson opinion is "the rule of law" versus "conscious lawlessness." But did the Chenery case differ from any other case in which an agency applies a statutory standard where it has not been applied before? The clue may lie in Mr. Justice Jackson's belief that the Commission was doing something different from

180 Id. at 210.

181 Id. at 216.

182 Id. at 217. In other contexts Justices Jackson and Frankfurter have encouraged agencies to create their own law through case-to-case development. Indeed, in FPC v. Hope Gas Co., 320 U.S. 591 (1944), they even wanted to allow the Commission to break down the statutory framework. The Court there freed the FPC from traditional methods of valuing utility property for rate-fixing, traditions that Mr. Justice Reed thought embodied in the statutory standard, "just and reasonable." The majority refused to go still further and free the Commission from the requirement of fair return on fair value. Justices Jackson and Frankfurter favored allowing the Commission "to fix the price of gas in the field as one would fix maximum prices of oil or milk or coal, or any other commodity. Such a price is not calculated to produce a fair return on the synthetic value of a rate base of any individual producer, and would not undertake to assure a fair return to any producer." Id. at 652. "Whether the Commission will assert its apparently broad statutory authorization over prices and discriminations is, of course, its own affair, not ours. It is entitled to its own notion of the 'public interest' and its judgment of policy must prevail .... If we return this case it may accept or decline the proffered freedom." Id. at 660 . Why wasn't this "administrative authoritarianism" and "conscious lawlessness"? Was it, perhaps, because Justices Jackson and Frankfurter saw clearly the need for getting away from fair return on fair value, just as the SEC in Chenery saw clearly the need for getting away from a practice of permitting the management to profit by buying securities of the corporation under reorganization? 
what a court or an agency usually does in deciding a case of first impression. Mr. Justice Jackson said that "to promulgate a general rule of law, either by regulation or by case law, is something the Commission expressly declined to do." ${ }^{183}$ That statement seems to be the foundation for the whole dissenting position. And that statement is demonstrably mistaken. The Commission did decline to issue a regulation. But it did not decline to declare a general rule "by case law." The Commission did what courts commonly do; it decided the case before it, keeping generalization to a minimum. The dominant approach is indicated by the Commission's statement of the problem: "The problem is whether the particular plan before us, under the particular circumstances of the case, meets the standards prescribed by the Holding Company Act." 184 But the Commission, like any other opimion writer, resorted in some measure to generalization: "When it is shown, as in this case, that the reorganization managers had both the incentive and the necessary powers to arrange for such a bargain, which would be realized through the reorganization plan if effect is given to the pending amendment, we do not need to look for affirmative proof as to their intentions." 185 The Commission even expressed a "principle" which it explicitly said was "generally applicable": "The important principle which we think generally applicable is that reorganization managers ... must not be permitted to engage in transactions, for their own profit, which injure or endanger the welfare of investors during the period in which reorgamization is in contemplation or pending under the Holding Company Act."186

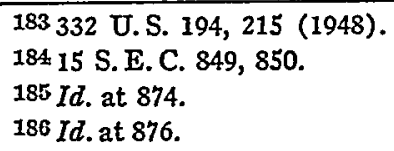

Mr. Justice Jackson might possibly have thought that the SEC was not merely changing the law in the Chenery case but was singling out the Chenery case for special treatment not given other similar cases either before or after. Such a behef might justify the vehemence of his opinion. But nothing in the Jackson opinion, in the record, or in the briefs supports this interpretation. The fact is that after the Supreme Court's decision in the second Chenery case, in the Cities Service case, Holding Co. Act Release No. 7720 (Oct. 1, 1947), and in American States Utilities Corp., Holding Co. Act Release No. 7721 (Oct, 3, 1947), the SEC permitted officers and directors who purchased securities of the corporations during their reorganization to participate equally in the reorganization with other stockholders. In each of these cases, the SEC wrote an opmion distinguishing its Chenery holding. This apparent shift of the Commission's position was called to the attention of the Supreme Court only through a document entitled, "Supplement to Petition of Federal Water and Gas Corporation for Rehearing," filed with the Court Oct. 8, 1947. The Court's decision was announced June 23, 1947, and the Jackson dissenting opinion was filed Oct. 6, 1947. 332 U.S. 747. Rehearing was denied Oct. 13, 1947, 332 U.S. 783. 
The secondary reliance of the Jackson opinion is on the retroactive feature of the Commission's decision. But is this kind of retroactive law-making deserving of condemnation? Nearly all adjudication, judicial and administrative, involves some degree of retroactive law-making, sometimes no more than a refinement of previously existing law in the application of legal concepts to the facts of the particular case. A clarification of uncertain law through adjudication is universally accepted as necessary and proper. Not retroactive clarification of uncertain law but retroactive change in settled law is what gives rise to problems of propriety of retroactive law-making, and any degree is possible. ${ }^{187}$ Another variable depends upon the substantive result of the retroactive law; imposition of a severe sanction is different from changing the amount of a tax or depriving a party of speculative profits.

The degree of retroactive law-making in which the courts customarily indulge, without adverse criticism, goes far beyond that of the Chenery case. Most landmark cases of the common law involve a large degree of the retroactive element. MacPherson v. Buick Motor $C 0 .{ }^{188}$ for instance, was an abrupt change. True, retroactive change in tort law is more readily acceptable than retroactive change in property law or criminal law. The Supreme Court in Shelley v. Kraemer ${ }^{189}$ retroactively changed the law of restrictive covenants, and the criticisms of the case went to the merits, not to retroactivity. The common law of crimes has been built retroactively, sometimes by long jumps, as in Rex v. Pear, ${ }^{100}$ which in 1779 for the first time brought into the law the concept of larceny by trick; Mr. Pear's act was not criminal when he committed it, ${ }^{101}$ and yet a death sentence was upheld. Today

${ }^{187}$ See Cardozo, The Nature of the Judicial Process 145-48 (1921). "In each system, hardship must at times result from the postponement of the rule of action till a time when action is complete. It is one of the consequences of the limitations of the human intellect and of the denial to legislators and judges of infinite prevision . . . . I think it is significant that when the hardship is felt to be too great or to be unnecessary, retrospective operation is withheld. Take the cases where a court of final appeal has declared a statute void, and afterwards, reversing itself, declares the statute valid. ... Most courts in a spirit of realism have held that the operation of the statute has been suspended in the interval .... We will not help out the man who has trusted to the judgment of soine inferior court . . .."

188217 N.Y. 382, 111 N. E. 1050 (1916).

189334 U.S. 1 (1948).

1902 East P. C. 685 (1779).

101 See Hall, Theft, LAw aNd SOcIETx 11 (1935): "Larceny by trick was not ... the product of legislative enactment. It may, in fact, be attributed entirely to Pear's Case ...." 
that degree of retroactivity probably would not be tolerated. But even in the criminal law we still make law retroactively; United States $v$. South-Eastern Underwriters Assn. ${ }^{192}$ was a criminal case involving an overruling of long-established precedents.

The SEC in the Chenery case was doing substantially what courts customarily do-without criticism-in similar circumstances. For instance, before enactment of the Chandler Act in 1938, neither statutory law nor case law condemned the purchase and sale by members of reorganization committees of securities of a corporation under reorganization in bankruptcy; yet three district courts and one circuit court of appeals held during the period from 1935 to 1941 that such dealings should be penalized by denial of compensation. ${ }^{193}$ Such retroactive application of judge-made law is hardly distinguishable from the retroactive application of agency-made law in the Chenery case. The difference is that the judge-made law was breaking new ground, whereas when the SEC made its decision the ground had already been broken by the judicial decisions, one of which had been cited by the Supreme Court with approval, ${ }^{194}$ and all of which had in effect been approved by Congress through a specific provision in the Chandler Act. ${ }^{105}$

A more persuasive dissenting opinion in the Chenery case might have been written by recognizing that the degree of the Commission's retroactive law-making was substantially the same as that which has long been accepted in the judicial process, but by emphasizing that agencies should not necessarily be allowed to imitate courts in this respect. The chief difference is that agencies can use techniques not easily available to courts for avoiding or softening the retroactive element. One such technique is rule-making. That a court, having no rule-making power, makes law retroactively through adjudication does not mean that an agency may leave its rule-making power unused and act only through adjudication no matter how serious may be the disadvantage of retroactive law-making in the circumstances. True, the Commission declared that a satisfactory rule could not be

192322 U.S. 533 (1944).

103 In re Mountain States Power Co., 35 F. Supp. 307 (D. Del. 1940), affd, 118 F. 2d 405 (3d Cir. 1941); In re Republic Gas Corp., 35 F. Supp. 300 (S.D.N.Y. 1936) ; In re Paramount-Publix Corp., 12 F. Supp. 823 (S.D.N.Y.1935). See Dodd, The Chenery Corporation Case, 56 HARv. L. REv. 1002, 1004 (1943).

194 See American Ins. Co. v. Avon Park, 311 U.S. 138, 147 (1940), citing In re Paramount-Publix Corp., 12 F. Supp. 823 (S.D.N.Y. 1935).

10552 STAT. 901 (1938), 11 U.S. C. $\S 649$ (1946). 
formulated. But that statement is unconvincing, for even though widely varying details and circumstances might go to the essence, a rule could be flexible in any desired degree-it could forbid corporate managers to profit by purchase of the corporation's securities during the reorganization whenever the Commission finds such a purchase to be detrimental to investors, or it could prohibit such profit except when the Commission specifically approves. Apart from rule-making, the Commission in this case, had it been sufficiently foresighted, might have mitigated the retroactive elenent by advance notice of what was contemplated. It might have taken a leaf from FCC practices and have given a warming through a dictum, a Commissioner's speech, a publicized letter, or a press release. ${ }^{100}$ Unlike a court, a commission need not refrain from taking a position, or a tentative position, until the time comes for announcement of a decision in a particular case..$^{107}$

A dissenting opinion-or a majority opinion-might have been written along such lines. But should it have been? The agencies should of course strive to achieve the exceedingly high standards of performance that such an opinion would require. And courts should miss no opportumity to encourage such striving. But for the courts to hold illegal, unfair, unauthorized, or unconstitutional what are substantially the same methods of law development that are traditional in the judicial system may seem to many to be incongruous and impracticable.

196 The idea of an informal warning is persuasively presented in Note, 62 HARv. L. REV. 478 (1949). For a discussion of highly developed FCC practices of this sort, see the writer's Administrative Powers of Supervising, Prosecuting, Advising, Declaring, and Informally Adjudicating, 63 HARv. L. REV. 193 (1949).

197 Interestingly enough, even a court sometimes ingeniously contrives a way to giving warning of an impending overruling. An outstanding instance is a concurring opinion of Mr. Justice Douglas in Fidehty Co. v. Rothensies, 324 U.S. 108, 112-13 (1945): "We are not faced with the question whether May v. Heiner . . . should survive Helvering v. Hallock ...." Of course, one might ask, if the Court was not faced with that question, why mention it? Might not the reason have been to give notice of the contemplated overruling of May v. Heiner, which came in Comm'r v. Estate of Church, 335 U.S. 632 (1949)? 